\title{
Rodzaje śmierci komórki
}

\section{Types of cell death}

\author{
Roman Paduch', ${ }^{1}$, Maria Klatka ${ }^{3}$, Janusz Klatka ${ }^{4}$ \\ ${ }^{1}$ Zakład Wirusologii i Immunologii Uniwersytetu Marii Curie-Skłodowskiej w Lublinie \\ ul. Akademicka 19, 20-033 Lublin \\ Kierownik: prof. dr hab. n. med. Martyna Kandefer-Szerszeń \\ ${ }^{2}$ Klinika Okulistyki Ogólnej Katedry Okulistyki Uniwersytetu Medycznego w Lublinie \\ ul Chmielna 1, 20-079 Lublin \\ Kierownik: prof. dr hab. n. med. Robert Rejdak
}

${ }^{3}$ Klinika Endokrynologii i Diabetologii Dziecięcej Uniwersyteckiego Szpitala Dziecięcego w Lublinie

ul. Prof. Antoniego Gębali 6, 20-093 Lublin

Kierownik: dr hab. n. med. Iwona Bień-Skowronek

${ }^{4}$ Katedra i Klinika Otolaryngologii i Onkologii Laryngologicznej Uniwersytetu Medycznego w Lublinie

ul. K. Jaczewskiego 8, 20-090 Lublin

Kierownik: prof. dr hab. n. med. Janusz Klatka

\section{SUMMARY}

Homeostasis in the body is maintained by multiple processes, including the balance between the formation of new cells and their dying. This paper describes the mechanism and pathways of apoptotic cell death, and the phenomenon of necrosis and autophagy. Furthermore, it describes rarely presented types of cell death, namely mitotic catastrophe, oncosis and pyroptosis. The course of these processes varies, as emphasized in the paper, and is on the one hand connected with maintaining the stability of tissues in physiological processes, but on the other hand processes of cell death are connected with the induction and progression of pathological processes. In the paper an attempt was made to show the basic differences between the described processes and their importance for the body.

Key words: apoptosis, autophagy, mitotic catastrophe, necrosis, oncosis, pyroptosis.

\section{STRESZCZENIE}

Homeostaza w organizmie utrzymywana jest przez wiele procesów, w tym również dzięki zachowywaniu równowagi między pojawianiem się nowych komórek a ich umieraniem. W pracy opisano mechanizm i szlaki apoptotycznej śmierci komórek oraz zjawisko nekrozy i autofagii. Ponadto opisano rzadziej prezentowane typy umierania komórek, a mianowicie katastrofę mitotyczną, onkozę i pyroptozę. Przebieg tych procesów jest

zróżnicowany, co podkreślono w pracy, a także związany z jednej strony z utrzymaniem stabilności tkanek w przebiegu procesów fizjologicznych, a z drugiej z indukcją i progresją procesów patologicznych. W pracy starano się przedstawić podstawowe różnice między opisywanymi procesami i ich znaczenie dla organizmu. Słowa kluczowe: apoptoza, autofagia, katastrofa mitotyczna, nekroza, onkoza, pyroptoza.

\section{WSTĘP}

Stopień komplikacji procesów regulujących prawidłowe funkcjonowanie wielokomórkowych organizmów wymusza na nich ścisłą kontrolę zarówno przebiegu zjawisk wewnątrzkomórkowych, jak i ilości samych komórek tworzących prawidłowo działający układ. Istotnym zjawiskiem jest również utrzymanie stałej równowagi wewnętrznej komórki (pH czy ciśnienie osmotyczne), która umożliwia prawidłowy przebieg procesów metabolicznych i katabolicznych, a tym samym prawidłowe funkcjonowanie komórki. Homeostaza w organizmie utrzymywana jest więc przez wiele procesów, w tym również równowagę między pojawianiem się nowych komórek a ich umieraniem. Stan równowagi wielu parametrów w ustroju pozwala na zabezpieczenie organizmu przed nieprawidłowościami wynikającymi m.in. z nadmiernej proliferacji komórek w tkankach czy narządach, które mogą prowadzić do rozwoju wielu

chorób, w tym łagodnych zmian lub nowotworów złośliwych. Stałym zjawiskiem w organizmie jest więc ciągła wymiana lub usuwanie zmutowanych i uszkodzonych komórek w celu utrzymania prawidłowych funkcji całego ustroju oraz ochrony przed chorobami $[1,2]$.

Historia obserwacji i badań nad eliminacją komórek z organizmu sięga 1882 r., kiedy Ilja Miecznikow odkrył proces fagocytozy i jej znaczenie dla odporności organizmów. Badania te wspólnie z odkryciami Paula Ehrlicha zostały w 1908 r. uhonorowane Nagrodą Nobla. Na początku lat 70. XX w. John Kerr, Andrew Wyllie i Adrian Curie wysunęli koncepcję, zgodnie z którą ściśle zorganizowane samounicestwienie komórek w warunkach patologicznych, lecz również w prawidłowych, jest jak najbardziej normalnym zjawiskiem w rozwijającym się organizmie. Nazwali je programowaną śmiercią komórki (programmed cell death). Zasugerowali również, że komórki mogą obumierać na drodze dwóch odmiennych procesów. 
TABELA 1. Charakterystyczne cechy śmierci apoptotycznej i nekrotycznej

\section{Apoptoza}

nieprawidłowe sygnały ze środowiska lub rozprzęgnięcie metaboliczne lub genetyczne

kurczenie się komórki i zmiany w jądrze komórkowym

rozpad cytoszkieletu, organelle komórkowe nienaruszone, zachowana ciągłość błony komórkowej. powstają ciałka apoptotyczne

DNA cięte na fragmenty o długości od 180 do 200 par zasad

brak stanu zapalnego

proces czynny, fizjologiczny, dotyczący pojedynczych komórek

Pierwszy z nich nazwali apoptozą, natomiast drugi nekrozą (tab. 1) $[3,4,5,6,7]$.

Apoptoza (gr. apoptosis - opadanie liści) jest to proces zaprogramowanej, samobójczej śmierci komórki. Przebiega on z udziałem:

- szlaku wewnętrznego (intrisic; mitochondrialny; P53-zależny),

- szlaku zewnętrznego (extrinsic; receptorowy),

- szlaku wykorzystującego perforyny i granzym B (pseudoreceptorowy),

- szlaku wykorzystującego retikulum endoplazmatyczne (siateczkowy; indukowany stresem) - rycina $1[8,9,10]$.

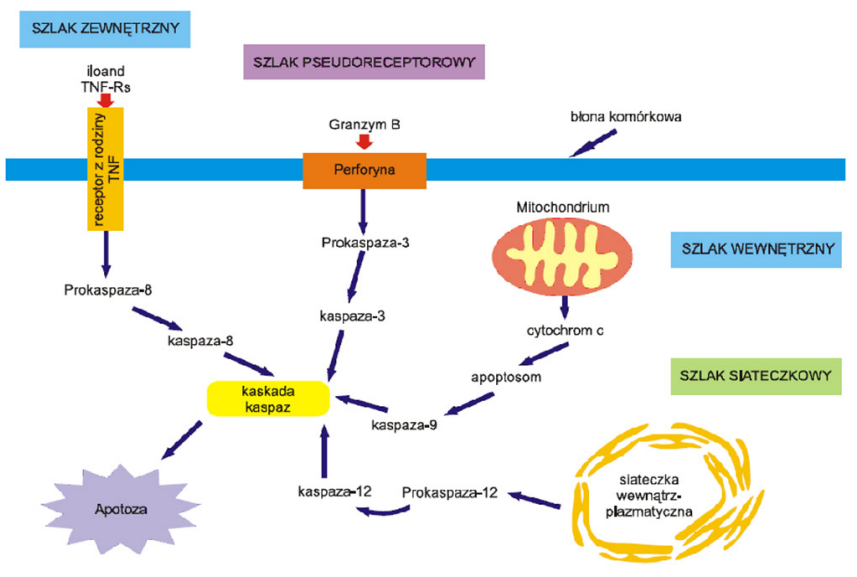

RYCINA 1. Główne szlaki apoptozy

Niezależnie jednak od wykorzystywanego szlaku, w cytoplazmie umierającej komórki aktywowane są cysteinowe proteazy z rodziny ICE, zwane kaspazami (caspases - cysteine-dependent aspartate-directed proteases). Nazwa pochodzi od pierwszej zidentyfikowanej kaspazy w komórkach ssaków, będącej enzymem konwertującym interleukinę-1 $\beta$ (interleukin-1 $\beta$ converting enzyme - ICE). Kolejne badania wykazały obecność dalszych enzymów o aktywności kaspaz podobnych do ICE. Z uwagi na etap procesu apoptozy, w którym aktywowane są poszczególne enzymy, podzielono je na kaspazy indukujące (aktywatorowe, sygnałowe, górne; -2, -8 i -9, -10 i -12) oraz kaspazy wykonawcze (egzekutorowe, efektorowe, dolne; -3, $-6,-7)$. Są one produkowane i przechowywane w komórce w postaci nieaktywnych zymogenów (pro-kaspaz). Aktywowane są dopiero w momencie zainicjowanego procesu apoptozy. Kaspazy indukujące są aktywne w formie dimerycznej,
Nekroza

uszkodzenie komórki przez czynniki fizyczne lub mechaniczne nabrzmienie komórki i perforacja błony komórkowej

rozpad komórek przy udziale enzymów lizosomalnych przypadkowe cięcia DNA

stan zapalny

proces bierny, patologiczny, dotyczący całych grup komórek

natomiast wykonawcze aktywowane są poprzez proteolityczne cięcie przez kaspazy aktywatorowe. Wszystkie kaspazy tną łańcuch białkowy docelowo w miejscu po kwasie asparaginowym. Jest to ich cecha charakterystyczna. Ponadto aktywują same siebie. Stąd też aktywacja jednej z kaspaz wywołuje reakcję określaną jako kaskada lub łańcuch aktywacji kaspaz. Enzymy te degradują zarówno białka strukturalne, jak i enzymatyczne. Jednym z kluczowych białek ulegających pocięciu jest polimeraza poli(ADP-rybozy), która w warunkach prawidłowych odpowiedzialna jest za naprawę DNA. Ponadto trawione są również: białko Rb uczestniczące w regulacji cyklu komórkowego, MDM-2 wiążące białko P53 i stabilizujące je, czy białka cytoszkieletu komórkowego. Sygnał przenoszony przez kaspazy prowadzi do indukcji czynników transkrypcyjnych, jak AP-1 (dimer powstały po połączeniu białek c-fos i c-jun) oraz NF- $\kappa$ B (powstały i aktywny po fosforylacji i oddysocjowaniu czynnika IкB). Prowadzi to w konsekwencji do pojawienia się w cytoplazmie wielu białek zaburzających strukturę i funkcje metaboliczne komórki, co przyczynia się do jej śmierci $[7,11,12,13]$.

\section{SZLAK WEWNĘTRZNY}

Punktem centralnym szlaku wewnętrznego są mitochondria. W wyniku wzrostu stężenia jonów wapniowych $\left(\mathrm{Ca}^{2+}\right)$, reaktywnych form tlenu (reactive oxygen species - ROS), wybranych cytokin (np. interferon), niedoboru hormonów, nieprawidłowych sygnałów dotyczących podziału komórki, komórek układu immunologicznego (np. limfocytów T), działania patogenów (np. wirusów, bakterii i ich produktów), czynników fizycznych czy nieprawidłowo sfałdowanych białek następuje aktywacja procesu apoptozy. W jego regulacji biorą udział zarówno czynniki hamujące, jak i promujące śmierć komórki. Wpływają one na aktywację kaspaz, przepuszczalność błon mitochondrialnych oraz interakcje z białkami pośredniczącymi w rozpadzie komórki. W warunkach stresowych białko $\mathrm{P}_{53}$ przemieszcza się z cytoplazmy do mitochondrium, gdzie tworzy kompleks z białkami Bcl-2/Bcl-X $\mathrm{X}_{\mathrm{L}}$. Prowadzi to do uwolnienia cytochromu c (czynnik Apaf-2) z przestrzeni międzybłonowej mitochondrium i aktywacji kaspaz. Istotnym elementem struktury związanym z wypływem cytochromu c z mitochondrium są tzw. megakanały mitochondrialne PTP (permeability transition pore), które zlokalizowane są w punktach styku między wewnętrzną i zewnętrzną błoną tego organellum. Istnieją 
koncepcje zakładające, że białko Bax ulega oligomeryzacji w błonie mitochondrialnej, umożliwiając wypływ czynników proapoptotycznych. Niezależnie jednak od mechanizmu uwalniania cytochromu c w cytoplazmie, wiąże się on z białkowym czynnikiem Apaf-1 oraz prokaspazą 9. W konsekwencji powstaje trójskładnikowy układ nazywany apoptosomem.

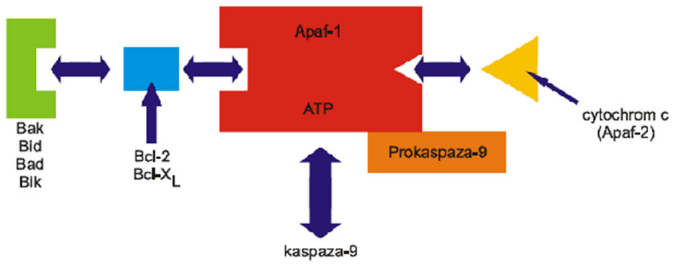

RYCINA 2. Składowe apoptosomu

Dodatkowym elementem apoptosomu jest fragment składający się z białek blokujących apoptozę Bcl-2/Bcl-X $\mathrm{L}_{\mathrm{L}}$. Jest to element regulatorowy apoptosomu. Do niego przyłączane są białka Bid, Bad, Bik i Bad o funkcji proapoptotycznej. Wiążą się one z kompleksem Bcl-2/Bcl-X $\mathrm{L}_{\mathrm{L}}$ unieczynniając go, przez co prowadzą do aktywacji kaspazy-9 (ryc. 2). Utworzenie apoptosomu wymaga nakładów energetycznych pochodzących z hydrolizy ATP. Jego główne zadanie to aktywacja kaspaz efektorowych. Jednak jakiekolwiek zmiany w budowie apoptosomu pojawiające się na etapie tworzenia białka lub związane z posttranslacyjną modyfikacją białek zaburzają lub wręcz hamują apoptotyczną śmierć komórki. W procesie aktywacji szlaku wewnętrznego apoptozy obok cytochromu c zaangażowanych jest ponad 40 dodatkowych białek, do których należy mitochondrialny czynnik AIF (apoptosis inducing factor) przenoszony do jądra komórkowego podczas inicjacji apoptozy. Wpływa on na kondensację chromatyny, fragmentację DNA oraz spadek mitochondrialnego potencjału błonowego. Ponadto endonukleaza G uwalniana z mitochondrium w jądrze komórkowym trawi DNA i wspólnie z egzonukleazami oraz DNA-zami tworzy odcinki o charakterystycznej długości 180200 par zasad $[7,14,15,16,17]$.

\section{BIAŁKO P53}

Białko P53 jest kluczowym czynnikiem w wewnętrznym szlaku apoptozy. Jest to czynnik, który hamuje podziały komórki, umożliwiając naprawę uszkodzonego materiału genetycznego. $\mathrm{Z}$ tego powodu nazywany jest czasem strażnikiem genomu. Jeśli uszkodzenia DNA nie mogą być naprawione, białko P53 aktywuje samobójczą śmierć komórki. Jest to więc element proapoptotycznej regulacji. W warunkach stresu przemieszcza się ono z cytoplazmy do mitochondrium, gdzie tworzy kompleks z antyapoptotycznymi białkami Bcl-2/Bcl- $\mathrm{X}_{\mathrm{L}}$. Powoduje to ich unieczynnienie, zwiększenie przepuszczalności błony mitochondrialnej i uwolnienie cytochromu c. W większości nowotworów następuje mutacja w genie kodującym białko P53. Prowadzi to do zahamowania apoptozy komórek i rozwoju guza. Podobny efekt obserwowany jest w przypadku nadekspresji genów dla białek antyapoptotycznych Bcl-2 i Bcl$-\mathrm{X}_{\mathrm{L}}[18,19]$.

\section{BIAŁKA Z RODZINY BCL-2}

Nazwa białek z rodziny Bcl-2 pochodzi od białaczkowej linii komórkowej (B cell leukemia/lymphoma-2). Ze względu na budowę i funkcje podzielono je na:

- białka antyapoptotyczne (np. Bcl-2, Bcl-X $\mathrm{L}_{\mathrm{L}}$ Bcl-w),

- białka proapoptotyczne (np. Bak, Bax, Bcl-X $\mathrm{X}_{\mathrm{S}}$ ),

- białka proapoptotyczne (np. Bid, Bad, Bik).

Najczęściej badane są białka Bcl-2 i Bcl-X $\mathrm{L}_{\mathrm{L}}$ które tworzą heterodimery z białkami proapoptotycznymi, uniemożliwiając przebieg apoptozy. Ponadto białka Bcl-2 i Bcl-X $\mathrm{L}_{\mathrm{L}}$ połączone z czynnikiem Apaf-1 uniemożliwiają tworzenie apoptosomu, hamując tym samym aktywację kaspazy-9 i proces apoptozy. Rodzina białek Bcl-2 reguluje również wypływ cytochromu c z mitochondrium, aktywację kaspaz i DNA-az czy stan równowagi oksydoredukcyjnej w komórce. 0 ewentualnym przeżyciu komórki lub jej apoptotycznej śmierci decyduje jednak stosunek białek o aktywności proapoptotycznej do białek antyapoptotycznych (tab. 2) [12, 20, 21, 22].

TABELA 2. Czynniki blokujące i stymulujące apoptozę

\begin{tabular}{ll}
\multicolumn{1}{c}{ Czynniki blokujące apoptozę } & Czynniki stymulujące apoptozę \\
\hline Bcl-2, Bcl-X, Bcl-w & Bak, Bax, Bcl-X, Bid, Bad, Bik \\
\hline $\begin{array}{l}\text { białka szoku termicznego } \\
\text { (cytoplazmatyczne) }\end{array}$ & $\begin{array}{l}\text { białka szoku termicznego } \\
\text { (mitochondrialne) }\end{array}$ \\
\hline
\end{tabular}

Podczas procesu apoptozy dochodzi do wielu charakterystycznych zmian w komórce, które prowadzą do jej zniszczenia. Najbardziej charakterystyczne jest kurczenie się komórki w wyniku utraty wody - powierzchnia komórki staje się asymetryczna, pofałdowana, fosfatydyloseryna przemieszcza się z wewnętrznej do zewnętrznej warstwy błony cytoplazmatycznej, następują zmiany w chromatynie jądrowej polegające na jej zagęszczeniu i gromadzeniu się wokół błony jądrowej. W miarę obkurczania się komórki chromatyna zaczyna wypełniać całe jądro komórkowe, cytoplazma staje się gęsta z ciasno upakowanymi organellami. Następnie jądro komórkowe ulega fragmentacji i pojawiają się tzw. ciałka apoptotyczne. Są to fragmenty zagęszczonej cytoplazmy, chromatyny i organelli komórkowych otoczone błoną komórkową. Ich zawartość nie wydostaje się na zewnątrz, tym samym nie wywołuje reakcji zapalnej. W ostatnim etapie fragmenty apoptotycznych komórek ulegają fagocytozie przez makrofagi lub otaczające komórki [7, 23].

\section{SZLAK ZEWNĘTRZNY}

Zewnątrzpochodną ścieżkę apoptozy inicjuje ograniczona ilość czynników wzrostowych czy substancji odżywczych, jak 


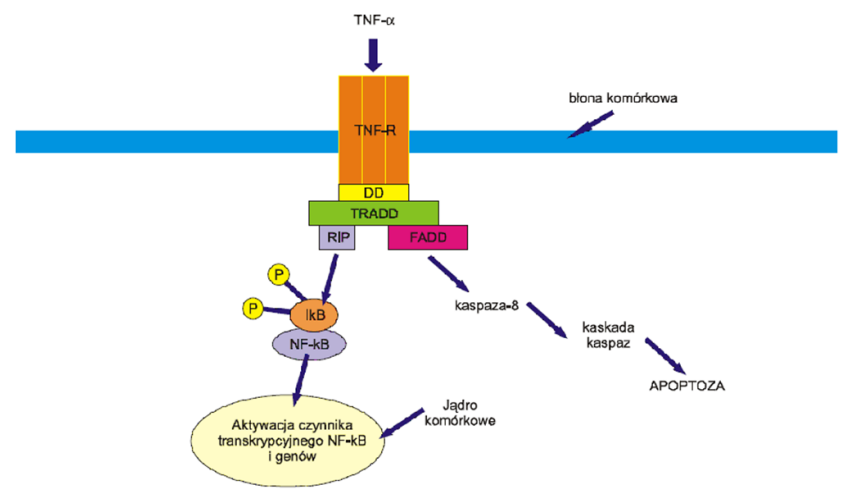

RYCINA 3. Przekazywanie sygnału proapoptotycznego przez receptory z rodziny TNF w szlaku zewnętrznym

również lokalny wzrost stężenia hormonów i cytokin. Ponadto czynnikami uruchamiającymi szlak receptorowy apoptozy są substancje chemiczne, m.in. cytostatyki oraz czynniki fizyczne, np. różne rodzaje promieniowania i temperatura. Sygnał proapoptotyczny przekazywany jest za pośrednictwem receptorów z rodziny TNF (TNF-RI [p55TNF-R], TNF-RII [p75TNF-R], Fas/APO-1/CD95, DR-3/TRAMP oraz DR-4/ TRAIL-R1 i DR-5/TRAIL-2). Receptory z rodziny TNF były opisane jako pierwszy model apoptozy, którą indukuje połączenie ligandu z receptorem śmierci. Przyłączenie odpowiedniego ligandu do receptora indukuje przekazanie sygnału poprzez domenę śmierci (death domain - DD) białka FADD (fas-associated death domain) do kaspazy-8. Połączenie pro-kaspazy-8 z białkiem FADD odbywa się poprzez domeny efektorowe śmierci (death effector domain - DED). Następuje aktywacja kaspazy-8 i przekazanie sygnału na kaspazy efektorowe. Formą aktywną rodziny receptorów TNF jest trimer. Receptor po związaniu ligandu i konformacyjnej modyfikacji swojej budowy przyłącza adaptorowe białko FADD. Ono dalej łączy się z pro-kaspazą-8. Aby sygnał mógł być przekazany, niezbędne jest również włączenie białka RIP (receptor-interacting protein) w kompleks receptorowy przy udziale białka TRADD (TNFR-associated death domain) - rycina $3[15,24]$.

\section{SZLAK PSEUDORECEPTOROWY}

Oprócz typowego przekazania sygnału proapoptotycznego do wnętrza komórki przy udziale receptorów TNF istnieje również inny sposób zabicia komórki, wykorzystujący ziarnistości pochodzące z komórek układu immunologicznego wykazujących aktywność cytotoksyczną (limfocyty T cytotoksyczne, komórki NK czy neutrofile). Wytwarzają one dwa rodzaje białek. Są to granzymy i perforyny. Po rozpoznaniu komórki docelowej efektorowa komórka cytotoksyczna wiąże się z nią, po czym ulega polaryzacji (przemieszczenie ziarnistości cytotoksycznych w kierunku komórki docelowej) i degranuluje. Uwalniane perforyny wbudowują się w błonę komórki docelowej i tam polimeryzują. Jest to proces zależny od obecności jonów $\mathrm{Ca}^{2+}$. Polimeryzując, perforyna tworzy kanał, zwykle o średnicy ok. $14 \mathrm{~nm}$, utworzony z ok. 20 podjednostek (ryc. 4).

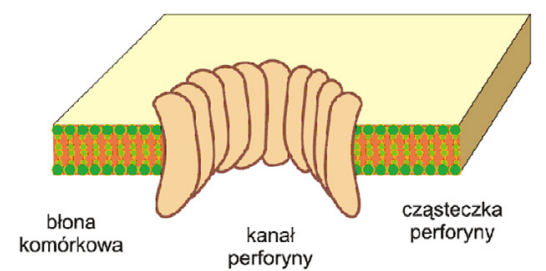

RYCINA 4. Schemat budowy kanału perforynowego zlokalizowanego w błonie komórki docelowej

Utworzony kanał umożliwia swobodny przepływ jonów, lecz również małych polipeptydów. W konsekwencji pojawia się niestabilność komórki, zaburzenia osmotyczności, utrata energii i destrukcja materiału genetycznego. Ponadto uwolnione jony wapnia dodatkowo stymulują apoptozę. Drugim elementem prowadzącym do zabicia komórki na drodze pseudoreceptorowej są granzymy (granule-associated enzymes). Są one protezami unikalnymi dla ziaren cytotoksycznych komórek efektorowych. Ich rola polega na aktywacji polimeryzacji perforyn, wnikaniu przez kanały perforynowe do wnętrza komórki docelowej, w której degradują białka integralne struktury, cy tosolowe i organella komórkowe. Wiążą się także i degradują białka chromatyny. Prowadzi to do odsłonięcia DNA dla endonukleaz i jego zniszczenia. W konsekwencji komórka docelowa zostaje zabita [25].

\section{SZLAK SIATECZKOWY}

Ten rodzaj śmierci komórki, wykryty i pierwszy raz opisany w 2000 r., wywoływany jest przez zaburzenie równowagi jonowej (szczególnie jonów $\mathrm{Ca}^{2+}$ ) oraz nagromadzenie się nieprawidłowo sfałdowanych lub zmodyfikowanych białek w komórce. Nieprawidłowości w budowie powodują, że białka te nie są transportowane do siateczki śródplazmatycznej. I właśnie retikulum endoplazmatyczne oraz zlokalizowana $w$ jego błonach kaspaza-12 są głównym elementem śmierci komórki. Kaspaza-12 bezpośrednio aktywuje pozostałe wykonawcze proteazy cysteinowe, tj. kaspazę-7 i kaspazę-8, prowadząc do apoptozy [26, 27, 28, 29].

W przebiegu procesu apoptozy wyróżniono:

- fazę wzbudzenia (indukcyjna) - rozpoznanie sygnału, jego modyfikację i przekazanie do wnętrza komórki,

- fazę wykonawcza - włączenie mechanizmów związanych ze zniszczeniem komórki,

- fazę zniszczenia (degradacji) - dochodzi do zniszczenia komórki na skutek fragmentacji DNA, rozpadu włókien cytoszkieletu, a utworzone ciałka apoptotyczne oraz pozostałe fragmenty komórki ulegają fagocytozie [7].

Apoptotyczna śmierć komórek następuje przy udziale kaspaz, lecz również wykazano, że istnieje szlak, który prowadzi do śmierci komórki bez udziału tych proteaz.

W szlaku niezależnym od kaspaz autonomiczną rolę w apoptozie pełni kalpaina, będąca protezą cysteinową aktywowaną jonami wapnia. Po zadziałaniu bodźca wapń uwalniany jest $\mathrm{z}$ retikulum endoplazmatycznego i wiąże się $\mathrm{z}$ wieloma 


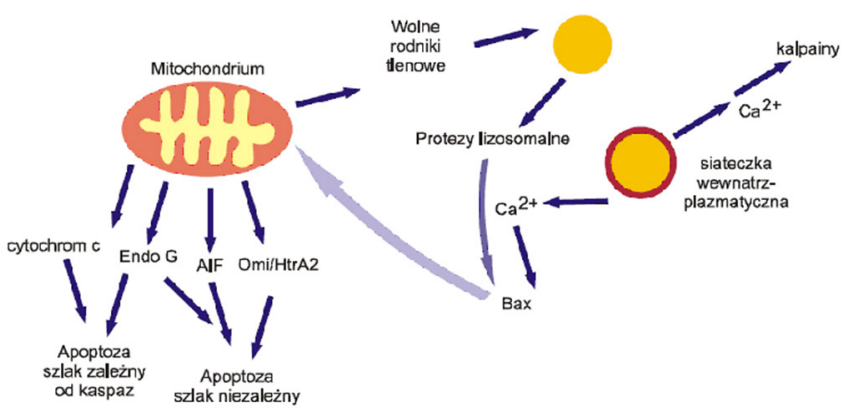

RYCINA 5. Wzajemne zależności między mitochondriami, lizosomami i retikulum endoplazmatycznym w przebiegu apoptozy. Szlaki zależne i niezależne od kaspaz

czynnikami, m.in. z kalpainą. Enzym ten aktywuje proapoptotyczne białka Bax czy Bid, które migrując do mitochondrium, powodują uwolnienie z niego cytochromu c oraz innych białek (Endo E, AIF, Omi/HtrA2) i indukcję śmierci komórki.

Ponadto w apoptozie niezależnej od kaspaz istotną rolę odgrywają inne proteazy (katepsyna D, proteza lizosomalna) trawiące białka struktury komórek lub wpływające na fragmentację DNA (ryc. 5) [30, 31, 32].

\section{NEKROZA}

Nekroza (martwica) wywoływana jest przez czynniki zewnętrzne, których nasilenie działa destrukcyjnie na komórki. Głównie obejmują one czynniki fizyczne (zarówno niska, jak i wysoka temperatura, promieniowanie radiacyjne i ulftrafioletowe) oraz czynniki mechaniczne. W wyniku ich działania następuje zaburzenie równowagi osmotycznej w komórce, wynikiem czego jest zahamowanie metabolizmu, spadek poziomu ATP pojawiający się w wyniku depolaryzacji błony mitochondrialnej i zaburzenia transportu elektronów, napływ wody i jonów do wnętrza komórki (szczególnie istotną rolę odgrywa poziom jonów $\mathrm{Ca}^{2+}$, biorący czynny udział w aktywacji nukleaz trawiących materiał genetyczny komórki), obrzęk organelli i całej komórki, trawienie elementów struktury komórki poprzez uwolnione enzymy z pękających lizosomów, a w konsekwencji jej rozpad i uwolnienie zawartości do przestrzeni pozakomórkowej. Proces ten prowadzi do rozwoju stanu zapalnego przyciągającego komórki fagocytarne. Rozpoznają one i pochłaniają fragmenty komórek nekrotycznych, wykorzystując mechanizmy zbieżne z fagocytozą komórek apoptotycznych. Różnica polega jednak na tym, że aktywacja fagocytów czy komórek dendrytycznych przez komórki nekrotyczne jest ściśle związana z hamowaniem wytwarzania czynników przeciwzapalnych (IL-10, TGF- $\beta$ ) i uwolnieniem cytokin promujących stan zapalny (TNF- $\alpha$, IL-1 $\beta$, IL-6 czy IL-8). Można więc uznać, że nekroza indukowana czynnikami fizycznymi lub chemicznymi jest prozapalną formą umierania komórek. Specyficznym rodzajem umierania komórek jest również nekroptoza, opisywana jako programowana nekroza zależna od aktywności białek kinazowych RIP1 i RIP3. W procesie tym, podobnie jak w typowej nekrozie, wywoływany jest lokalny stan zapalny [5, 33, 34, 35].

\section{AUTOFAGIA}

Autofagia, nazywana również II typem programowanej śmierci komórek, jest ewolucyjnie konserwatywnym autokatabolicznym procesem. Pojawia się w momencie niedoboru czynników odżywczych lub uszkodzeń elementów składowych komórki. Podstawową rolą tego procesu jest podtrzymywanie metabolizmu komórki w czasie głodzenia, zabezpieczenie przed gromadzeniem uszkodzonych białek lub toksyn podczas działania na komórkę czynników stresowych. Jest to więc proces mający na celu utrzymanie komórki przy życiu w warunkach narażenia na niekorzystne czynniki. Proces autofagii, mimo że w warunkach fizjologicznych występuje w ograniczonym zakresie, jest niezwykle istotny dla utrzymania żywotności i przeżywalności komórek w warunkach stresu poprzez selektywne usuwanie uszkodzonych komórek lub organelli komórkowych [36].

Autofagię cechuje degradacja składników struktury komórki bezpośrednio w jej wnętrzu, w tzw. wakuolach autofagosomalnych. Morfologicznie autofagię wyróżnia wakuolizacja, degradacja elementów cytoplazmatycznych i ograniczona kondensacja chromatyny. Badania nad tym procesem wskazują, że przebiega on w ściśle określonym i regulowanym schemacie. Autofagię rozpoczyna podział i związanie materiału cytoplazmatycznego w pęcherzykach autofagosomalnych utworzonych z podwójnej błony białkowo-lipidowej. Jest to proces przebiegający pod kontrolą GTPaz, kinaz fosfatydyloinozytolowych oraz w układzie nadzorowanym przez ubikwitynację. Autofagosomy ulegają następnie fuzji z lizosomami przy udziale mikrotubuli, a ich zawartość ulega zniszczeniu. W warunkach in vivo komórki, które ulegają śmierci poprzez autofagię, fagocytowane są przez otaczające sąsiednie komórki [37].

Wyróżniono trzy rodzaje autofagii:

- makroautofagię - formowanie autofagosomu, który ulegając fuzji z lizosomom, tworzy autofagolizosom; proces ten pełni istotną rolę w usuwaniu nieprawidłowych lub niepotrzebnych elementów komórkowych, utrzymując stabilność komórki,

- mikroautofagię - proces pochłaniania fragmentów komórkowych poprzez inwaginację (wpuklenie) błony lizosomów,

- autofagię zależną od białek opiekuńczych (chaperon-dependent autophagy).

Wykazanie określonych markerów nie zawsze świadczy o śmierci komórek na drodze autofagii. Proces ten musi spełniać pewne podstawowe kryteria, którymi są:

- typowe cechy morfologiczne związane ze śmiercią poprzez autofagię,

- brak znamion śmierci poprzez apoptozę lub nekrozę,

- śmierć komórki indukowana brakiem substancji odżywczych lub w obecności rapamycyny,

- możliwość zahamowania autofagii przez niezależne czynniki [38, 39].

Proces autofagii opisywany jest jednak jako miecz obosieczny. Jest on zaangażowany zarówno w utrzymanie zdrowia organizmu, jak i w promocję rozwoju różnych schorzeń, w tym nowotworów. W procesie nowotworzenia oraz w czasie terapii przeciwnowotworowych autofagia paradoksalnie 
odgrywa podwójną rolę, zarówno w promowaniu przeżywalności komórek, jak i ich śmierci. Rola tego procesu może ulegać zmianie w czasie rozwoju nowotworu oraz zmieniać się w zależności od stadium rozwoju choroby. Jako supresor nowotworzenia ogranicza akumulację uszkodzonych białek i organelli w komórkach, natomiast jako promotor nowotworzenia utrzymuje wzrost guzów oraz ich oporność na leczenie, m.in. poprzez podtrzymywanie stabilności energetycznej komórek. Badania laboratoryjne wskazują, że zahamowanie autofagii uwrażliwia komórki nowotworowe na cytostatyki oraz przyspiesza ich umieranie. Wskazuje się również na funkcjonalne interakcje między autofagią a innymi modelami śmierci komórek. W odpowiedzi na stres metaboliczny autofagia opóźnia apoptozę, z drugiej jednak strony autofagia może stanowić alternatywny model śmierci komórek, które są oporne na apoptozę. Z kolei inaktywacja ochronnej funkcji autofagii silnie promuje nekrotyczną śmierć komórek. Autofagia staje się więc swoistym celem terapeutycznym, którego modulacja daje nowe możliwości w walce z nowotworami [39, 40, 41, 42].

Rola autofagii wychodzi więc poza ramy utrzymania homeostazy, degradacji nieprawidłowych form białek czy organelli i obejmuje również swoiste fizjologiczne oraz patologiczne procesy, jak rozwój, odporność, stabilność energetyczna, śmierć komórek czy rozwój nowotworu.

\section{KATASTROFA MITOTYCZNA}

Istnieją doniesienia wskazujące na istnienie innych modeli umierania komórek, które przebiegają odmiennie niż apoptoza, nekroza czy autofagia. Jednym z nich jest katastrofa mitotyczna. Jest to śmierć komórki, która wynika z nieprawidłowości zachodzących podczas procesu mitozy. Wynika z wadliwego funkcjonowania punktów kontrolnych cyklu komórkowego i pojawienia się aneuploidalnych komórek, które muszą zostać usunięte. W trakcie nieprawidłowej mitozy tworzone są także komórki multiploidalne. Proces katastrofy mitotycznej zapoczątkowuje stabilizacja (np. taksany) lub destabilizacja (np. kolchicyna) mikrotubul oraz zniszczenie DNA. Pojawia się fragmentacja jądra komórkowego i tworzenie dużych komórek z jednym jądrem lub kilkoma mniejszymi. Komórki zabijane są podczas metafazy głównie w szlaku niezależnym od białka P53. Cechą charakterystyczną obrazującą śmierć mitotyczną są brak lub opóźnione wejście komórki w fazę G1/S czy zatrzymanie cyklu komórkowego w fazie G2 [43, 44].

Zakłada się, że w komórkach nowotworowych istnieją dwa odrębne mechanizmy śmierci mitotycznej:

- postać wczesna - zachodząca w komórkach, które zaczynają się dzielić tuż po zadziałaniu czynnika uszkadzającego i zanim zakończony zostanie proces replikacji DNA oraz synteza białek, kontrolująca prawidłowy przebieg tego procesu,

- postać opóźniona - zachodząca w komórkach, które weszły w cykl podziałowy, już po uprzednim zatrzymaniu ich wzrostu.

Katastrofa mitotyczna, według jednej grupy badaczy, związana jest z zapoczątkowaniem przepuszczalności błony mitochondrialnej i aktywacją kaspaz. Druga grupa badaczy sugeruje jednak, że w czasie tego procesu nie dochodzi do fragmentacji DNA typowej dla apoptozy, a szlaki związane z czynnikiem transkrypcyjnym NF- $\kappa \mathrm{B}$, charakterystycznym dla apoptozy, nie są uruchamiane. Nie jest jednak wykluczone, że podczas katastrofy mitotycznej apoptoza zachodzi, lecz poprzez szlaki niezależne od kaspaz. W związku z tym pojawiają się sugestie, że śmierć mitotyczna może nie być odmiennym modelem umierania komórek, lecz jedynie nieprawidłowo przebiegającą mitozą prowadzącą w konsekwencji do usunięcia wadliwych komórek poprzez apoptozę lub nekrozę [45].

\section{ONKOZA}

Onkoza („onkos” - opuchnięcie) jest określana jako pośredni etap umierania komórek prowadzący do apoptozy. Proces ten cechuje pęcznienie organelli i całych komórek na skutek wzrostu przepuszczalności błony komórkowej i nieprawidłowości w funkcjonowaniu pomp jonowych oraz pojawienie się ciałek apoptotycznych. W konsekwencji istotnemu obniżeniu ulega poziom energetyczny komórek i ich aktywność metaboliczna. Proces onkozy indukować mogą czynniki toksyczne interferujące z procesami produkcji komórkowego ATP oraz prowadzące do niekontrolowanego zużycia energii w komórce. Ponadto wzrost wewnątrzkomórkowego poziomu jonów $\mathrm{Ca}^{2+}$ jest również istotnym regulatorem onkozy. Aktywuje on proteazy z rodziny kalpain prowadzące do rozpadu błony komórkowej na skutek fragmentacji cytoszkieletu i integralnych białek błonowych [46, 47].

Wskazuje się również, że wirusy (rotawirusy) oraz bakterie (pseudomonas) mogą być przyczyną onkozy niektórych komórek (makrofagi, neutrofile) [46].

\section{PYROPTOZA}

Pyroptoza (gr. pyro - ogień, gorączka; ptosis - wpadać) jest specy ficzną formą umierania komórek opisywaną jako zależna od kaspazy-1 śmierć komórki wywołana zakażeniem bakteriami typu Salmonella i Shigella. Komórkami umierającymi na drodze pyroptozy są zwykle komórki fagocytujące bakterie, a mianowicie makrofagi. Wskazuje się, że śmierć makrofagów na drodze pyroptozy powodują najczęściej: Salmonella typhimurium, Shigella flexneri, Listeria monocytogenes oraz Pseudomonas aeruginosa. Pyroptoza nie jest jednak śmiercią typową jedynie dla makrofagów. Dotyczyć może również innych komórek wchodzących na drogę pyroptozy po zakażeniu bakteriami, wirusami, uszkodzeniami wywołanymi przez czynniki fizyczne lub nawet po terapii cytostatykami. Istotną funkcją kaspazy-1 w pyroptozie jest przekształcanie nieaktywnych proform cytokin prozapalnych (IL-1 $\beta$ i IL-18) do aktywnych czynników. Następuje to zanim pojawią się jakiekolwiek morfologiczne symptomy śmierci komórki. W wyniku tego procesu pojawia się stan zapalny, który w zdecydowany sposób odróżnia pyroptozę od apoptozy. Aktywność kaspazy-1 oraz 
TABELA 3. Rodzaje śmierci komórki i ich charakterystyczne cechy

Typ śmierci komórki

\begin{tabular}{ll}
\hline Apoptoza & $\begin{array}{l}\text { pośredniczą w niej proteazy cysteinowe (kaspazy); tworzone są ciałka apoptotyczne; nie dochodzi do rozwoju stanu } \\
\text { zapalnego }\end{array}$ \\
\hline Nekroza & rozpad komórki pod wpływem czynników stresowych; rozwija się stan zapalny \\
\hline Autofagia & $\begin{array}{l}\text { rozpad elementów komórkowych wewnątrz umierającej komórki; trawienie wewnątrz wakuol autofagalnych; nie } \\
\text { rozwija się stan zapalny. }\end{array}$ \\
\hline Katastrofa mitotyczna & $\begin{array}{l}\text { śmierć komórki, która wynika z nieprawidłowości zachodzących podczas procesu mitozy; wynika z wadliwego } \\
\text { funkcjonowania punktów kontrolnych cyklu komórkowego }\end{array}$ \\
\hline Onkoza & $\begin{array}{l}\text { proces ten cechuje pęcznienie organelli i całych komórek na skutek wzrostu przepuszczalności błony komórkowej; } \\
\text { ewentualnie pojawia się stan zapalny. }\end{array}$ \\
\hline Pyroptoza & $\begin{array}{l}\text { forma umierania komórek opisywana jako zależna od kaspazy-1 śmierć komórki wywołana zakażeniem bakteriami } \\
\text { typu Salmonella i Shigella; pojawia się stan zapalny }\end{array}$ \\
\hline Anoikis & $\begin{array}{l}\text { forma umierania (apoptozy) adherentnych komórek wynikająca z braku zakotwiczenia, połączenia z macierzą } \\
\text { pozakomórkową lub innymi komórkami. }\end{array}$ \\
\hline
\end{tabular}

zmiany w cytoszkielecie komórki, w wyniku których pojawiają się kanały (średnica 1-2 nm) w błonie cytoplazmatycznej, prowadzą z jednej strony do wypływania pozapalnych cytokin do środowiska, z drugiej zaś do pęcznienia komórki i jej rozerwania w wyniku zmian osmotyczności. Aktywność kaspazy-1 prowadzi dodatkowo do rozwoju i podtrzymania stanu zapalnego na drodze związanej z aktywnością IL-1 $\beta$ i IL-18. Interleukina $1 \beta$ wpływa na pobudzenie migracji leukocytów oraz aktywuje dodatkowo panel cytokin i chemokin działających wielokierunkowo podczas rozwoju stanu zapalnego. Z kolei IL-18 aktywuje limfocyty T oraz makrofagi do produkcji IFN- $\gamma$, IL-1 $\alpha$, IL-6 oraz TNF- $\alpha$, które utrzymują lokalny stan zapalny $[5,48,49,50]$.

Śmierć komórek na drodze pyroptozy zaobserwowano zarówno w układzie odpornościowym, jak i w centralnym układzie nerwowym oraz układzie sercowo-naczyniowym. Wskazuje to na istotną rolę tego procesu w prawidłowej regulacji wielu systemów oraz przebiegu wielu zjawisk w organizmie $[48,49,51]$.

W tabeli 3 przedstawiono porównanie cech charakterystycznych różnych typów umierania komórek.

Ze względu na różnorodność procesów umierania komórek możliwym podejściem terapeutycznym, np. w zwalczaniu chorób nowotworowych, może być ukierunkowywane uśmiercanie nieprawidłowych komórek. Mogłoby to się odbywać na drodze regulacji (aktywacja, hamowanie) swoistych szlaków istotnych dla przeżycia tych komórek. Ponadto swoiste wywoływanie apoptozy lub innego typu śmierci komórek nowotworowych we wczesnych stadiach rozwoju choroby mogłoby być także skutecznym postępowaniem chemoprewencyjnym.

\section{PIŚMIENNICTWO}

1. Chen M.J., Sepramaniam S., Armugam A., Choy M.S., Manikandan J., Melendez A.J. et al: Water and ion channels: crucial in the initiation and progression of apoptosis in central nervous system? Curr Neuropharmacol. 2008, 6 (2), 102-116.

2. Ponizovskiy M.R.: Biophysical and biochemical models of mechanisms of cellular development via the cellular cycle in normal tissue, cancerous tissue, and inflammatory processes. Crit Rev Eucaryot Gene Expr. 2013, 23 (2), 171-193.
3. Diamantis A., Magiorkinis E., Sakorafas G.H., Androutsos G.: A brief history of apoptosis: from ancient to modern times. Onkologie. 2008, 31 (12), 702-706.

4. Duque-Parra J.E.: Note on the origin and history of the term "apoptosis". Anat Rec B New Anat. 2005, 283 (1), 2-4.

5. Fink S.L., Cookson B.T.: Apoptosis, pyroptosis, and necrosis: mechanistic description of dead and dying eukaryotic cells. Infect Immunity. 2005, 73 (4), 1907-1916.

6. Manning F., Zuzel K.: Comparison of types of cell death: apoptosis and necrosis. J Biol Educ. 2003, 37 (3), 141-145.

7. Motyl T.: Apoptoza - śmierć warunkująca życia. Post Biol Komórki. 1998, 25, 315-334.

8. Fulda $S$.: Targeting apoptosis signaling pathways for anticancer therapy. Front Oncol. 2011, 1, 1-7.

9. Sinha K., Das J., Pal P.B., Sil P.C.: Oxidative stress: the mitochondria-dependent and mitochondria-independent pathways of apoptosis. Arch Toxicol. 2013, 87 (7), 1157-1180.

10. Stępień A., Izdebska M., Grzanka A.: Rodzaje śmierci komórek. Post Hig Med Dośw. 2007, 61, 420-428.

11. Bates W.R.: Cellular features of an apoptotic form of programmed cell death during the development of the ascidian, Boltenia villosa. Zoolog Sci. 2004, 21 (5), 553-563.

12. Engel T., Henshall D.C.: Apoptosis, Bcl-2 family proteins and caspases: The ABCs of seizure-damage and epileptogenesis? Int J Physiol Patophysiol Pharmacol. 2009, 1 (2), 97-115.

13. Li J., Yuan J.: Caspases in apoptosis and beyond. Oncogene. 2008, 27 (48), 6194-6206.

14. Czarnecka A.M., Golik P., Bartnik E.: Mitochondria jako integratory apoptozy. Post Biol Komórki. 2006, 33, 525-541.

15. Fulda S., Debatin K.M.: Extrinsic versus intrinsic apoptosis pathways in anticancer chemotherapy. Oncogene. 2006, 25 (34), 4798-4811.

16. Łabędzka K., Grzanka A., Izdebska M.: Mitochondrium a śmierć komórki. Post Hig Med Dośw. 2006, 60, 439-446.

17. Wu Ch.-Ch., Bratton S.B.: Regulation of the intrisic apoptosis pathway by reactive oxygen species. Antioxid Redox Signal. 2013, 19, 546-558.

18. Huo J.X., Metz S.A., Li G.D.: p53-independent induction of p21(waf1/cip1) contributes to the activation of caspases in GTP-depletion-induced apoptosis of insulin-secreting cells. Cell Death Differ. 2004, 11 (1), 99-109.

19. Schlereth K., Charles J.P., Bretz A.C., Stiewe T.: Life or death: p53-induced apoptosis requires DNA binding cooperativity. Cell Cycle. 2010, 9 (20), 4068-4076.

20. Czabotar P.E., Lessene G., Strasser A., Adams J.M.: Control of apoptosis by the BCL-2 protein family: implications for physiology and therapy. Nat Rev Mol Cell Biol. 2014, 15 (1), 49-63.

21. Martinou J.-C., Youle R.: Mitochondria in apoptosis: Bcl-2 family members and mitochondrial dynamics. Dev Cell. 2011, 21 (1), 92-101.

22. Ola M.S., Nawaz M., Ahsan H.: Role of Bcl-2 family proteins and caspases in the regulation of apoptosis. Mol Cell Biochem. 2011, 351 (1-2), 41-58.

23. Häcker G.: The morphology of apoptosis. Cell Tissue Res. 2000, 301 (1), 5-17. 
24. Sayers T.J.: Targeting the extrinsic apoptosis signaling pathway for cancer therapy. Cancer Immunol Immunother. 2011, 60 (8), 1173-1180.

25. Greenberg A.H.: Granzyme B-induced apoptosis. In: Mechanisms of lymphocyte activation and immune regulation VI. Eds: S. Gupta, J.J. Cohen. Springer, New York 1996, 219-228.

26. Breckeridge D.G., Germain M., Mathai J.P., Nguyen M., Shore G.C.: Regulation of apoptosis by endoplasmic reticulum pathways. Oncogene. 2003, 22 (53), 8608-8618.

27. Lamkanfi M., Kalai M., Vandenabeele P.: Caspase-12. An overview. Cell Death Differ. 2004, 11 (4), 365-368.

28. Martinon F.: Targeting endoplasmic reticulum signaling pathways in cancer. Acta Oncol. 2012, 51 (7), 822-830.

29. Su J., Zhou L., Kong X., Yang X., Xiang X., Zhang Y. et al.: Endoplasmic reticulum is at the crossroads of autophagy, inflammation, andapoptosis signaling pathways and participates in the pathogenesis of diabetes mellitus. J Diabetes Res. 2013, doi: 10.1155/2013/193461.

30. Broker L.E., Kruyt F.A.E., Giaccone G.: Cell death independent of caspases: a review. Clin Cancer Res. 2005, 11 (9), 3155-3162.

31. Candé C., Cohen I., Daugas E., Ravagnan L., Larochette N., Zamzami N. et al.: Apoptosis-inducing factor (AIF): A novel caspase-independent death effector released from mitochondria. Biochimie. 2002, 84 (3), 215-222.

32. Harwood S.M., Yaqoob M.M., Allen D.A.: Caspase and calpain function in cell death: bridging the gap between apoptosis and necrosis. Ann Clin Biochem. 2005, 42, 415-431.

33. Aki T., Funakoshi T., Uemura K.: Regulated necrosis and its implications in toxicology. Toxicology. 2015, 333, 118-126.

34. Gamrekalashvili J., Greten T.F., Korangy F.: Immunogenicity of necrotic cell death. Cell Mol Life Sci. 2015, 72 (2), 273-283.

35. Morgan M.J., Liu Z.G.: Programmed cell death with a necrotic-like phenotype. Biomol Concepts. 2013, 4 (3), 259-275.

36. Garg A.D., Maes H., Romano E., Agostinis P.: Autophagy, a major adaptation pathway shaping cancer cell death and anticancer immunity responses following photodynamic therapy. Photochem Photobiol Sci. 2015, 14 (8), 1410-1424.
37. Parzych K.R., Klionsky D.J.: An overview of autophagy: morphology, mechanism, and regulation. Antioxid Redox Signal. 2014, 20 (3), 460-473.

38. Jia G., Sowers J.R.: Autophagy: a housekeeper in cardiorenal metabolic health and disease. Biochim Biophys Acta. 2015, 1852 (2), 219-224.

39. White E.: Autophagic cell death unraveled: pharmacological inhibition of apoptosis and autophagy enables necrosis. Autophagy. 2008, 4 (4), 399-401.

40. Chen N., Karantza V.: Autophagy as a therapeutic target in cancer. Cancer Biol Ther. 2011, 11 (2), 157-168.

41. Rosenfeldt M.T., Ryan K.M.: The multiple roles of autophagy in cancer. Carcinogenesis. 2011, 32 (7), 955-963.

42. Yang Z.J., Chee C.E., Huang S., Sinicrope F.A.: The role of autophagy in cancer: therapeutic implications. Mol Cancer Ther. 2011, 10 (9), 1533-1541.

43. Vakifahmetoglu H., Olsson M., Zhivotovsky B.: Death through a tragedy: mitotic catastrophe. Cell Death Differ. 2008, 15 (7), 1153-1162.

44. Vriend L.E.M., De Witt Hamer P.C., Van Noorden C.J., Würdinger T.: WEE1 inhibition and genomic instability in cancer. Biochim Biophys Acta. 2013, 1836 (2), 227-235.

45. Castedo M., Perfettini J.L., Roumier T., Andreau K., Medema R., Kroemer $G$ : Cell death by mitotic catastrophe: a molecular definition. Oncogene. 2004, 23 (16), 2825-2837.

46. Weerasinghe P., Buja L.M.: Oncosis: an important non-apoptotic mode of cell death. Exp Mol Pathol. 2012, 93 (3), 302-308.

47. Xiao J., Liu D., Liu L.: Oncosis and its advances in medical researches. Chin J Forensic Med. 2005, 20, 158-160.

48. Bergsbaken T., Fink S.L., Cookson B.T.: Pyroptosis: host cell death and inflammation. Nat Rev Microbiol. 2009, 7 (2), 99-109.

49. Keep O., Galluzzi L., Zitvogel L., Kroemer G.: Pyroptosis - a cell death modality of its kind? Eur J Immunol. 2010, 40 (3), 627-630.

50. Magna M., Pisetsky D.S.: The role of cell death in the pathogenesis of SLE: is pyroptosis the missing link? Scand J Immunol. 2015, 82 (3), 218-224.

51. Bortoluci K.R., Medzhitov R.: Control of infection by pyroptosis and autophagy: role of TLR and NLR. Cell Mol Life Sci. 2010, 67 (10), 1643-1651. 